ICOSITER 2018 Proceeding

Journal of Science and Applicative Technology

\title{
Potential Analysis of Hydro Power Plants in Pesisir Barat District, Lampung Province
}

\author{
Kiki Kananda ${ }^{1}$, Dean Corio ${ }^{1}$, Hafif Restu K², Hilmi Aziz ${ }^{2}$, Topan Wira B $^{2}$, Diah A $^{2}$ \\ ${ }^{1}$ Electrical Engineering Department, Institut Teknologi Sumatera, Lampung Selatan, Lampung \\ ${ }^{2}$ Student of Electrical Engineering Department, Institut Teknologi Sumatera, Lampung Selatan, Lampung
}

\begin{abstract}
Hydropower plants are increasingly being heard nowadays, but the growth is still very lacking, especially for residents living in rural and coastal areas. At present several efforts have been made by the government, including the existence of a system of purchasing electricity from small-scale renewable energy generation and the construction of new transmission networks. Pesisir Barat Regency is part of the South Lampung region, Sumatra. This region has a population distribution in the coastal area and is surrounded by Bukit Barisan National Park. So that there are many large river streams that can be utilized by the local community. Large rivers have the potential to be utilized further as hydropower renewable energy sources. River potential is seen by conducting river location surveys, flow measurements and river heads and power calculations. Based on the analysis of measurement results there are two rivers that have the potential to be a micro or mini hydro generator; Way Laai and Way Lami. The maximum design discharge of Way Laai of $4.52 \mathrm{~m}^{3} / \mathrm{s}$ can produce a mechanical output power of $1223.82 \mathrm{~kW}$ with an effective head of $44.16 \mathrm{~m}$. Way Lami with a design discharge of $5,336 \mathrm{~m}^{3} / \mathrm{s}$, an effective head of $28.8 \mathrm{~m}$ has the potential to provide a mechanical power output of $942.23 \mathrm{~kW}$. Sequentially, with this mechanical output power, the Way Laai and Way Lami rivers, can meet the electricity needs of the community with an installed power of 900VA as much as $\pm 1350, \pm 25100$ Houses.
\end{abstract}

\section{Introduction}

Hydropower plants are increasingly being heard nowadays. But its growth is still very lacking, especially for residents living in urban and Regency areas. Even though at this time several efforts have been made by the government, including the existence of a system of purchasing electric energy from small-scale plants based on renewable energy. The limitations of many fossil fuel energy sources are felt by the community at the end of the transmission and distribution network. Several energy policies in Indonesia have been established, in order to encourage the fulfilment of electricity in Indonesia. The policy is also aimed at developing the use of new and renewable energy. Minister of Energy and Mineral Resources (Permen ESDM) Regulation No. 12 of 2017 concerning the utilization of renewable energy for electricity supply, which is an extension of Law No. 30 of 2007 concerning Energy. Then ESDM regulation number 39 of 2017 came out about the implementation of physical activities for the utilization of new and 
ICOSITER 2018 Proceeding

Journal of Science and Applicative Technology

renewable energy and conservation of energy. The Minister of ESDM also explained how electricity buying and selling can be done related to the renewable energy generation developed.

The Institut Teknologi Sumatera (ITERA) in supporting these government policies also contributed. ITERA has poured into the Institutional Strategy Plan that energy security is a field of development that must be achieved in the future to become an energy-independent campus. Previous research [1] has measured the potential of solar and wind energy in ITERA. Based on the results of these studies, the solar potential is potential to be built on campus as a renewable energy source. For hydro potential, then by utilizing the buying and selling system set by the ESDM minister, it is a big opportunity for ITERA to develop renewable energy in potential areas in Lampung.

Pesisir Barat Regency is part of the South Lampung region, Sumatra. The geographical condition is the distribution of the population in the coastal area. Many hills are part of the hills of the Sumatran line and also rivers. The daily lives of the majority of the population are fishermen, farmers, some factory workers and government employees. Distribution of population grouping according to potential supporters around. Consists of coastal land and banana island. Unfortunately, the condition of the electricity on the west coast is quite bad. The community can only enjoy electricity in the afternoon 3-5 hours. During that time the voltage conditions were also unstable. But the other side, in this region the fulfilment of clean water needs is abundant because there are many rivers. The rivers here are still used only to fulfil irrigation and clean water needs. So, the potential to be utilized further as a source of renewable energy for hydropower and even oil and gas. On the other side of this coastal area, many houses are scattered near the coast, coastal wind can be used as a source of electricity. Therefore, it is necessary to analyze the potential for further development of hydro and wind potential in the Pesisir Barat District area.

Hydroelectric Power Plant (PLTH) is the right solution to overcome the use of fuel oil and lack of electricity in remote areas and islands in Indonesia [2]. Indonesia has officially become one of the centres of PLTH technology learning and development in Southeast Asia. Hydroelectric power plants are an important energy source, but many people still do not know the important role of PLTH for national electricity supply. So, analysis of the potential of hydropower plants as scattered plants in the Pesisir Barat region can be done.

\section{Hydropower Plant}

PLTH is a generator that is relied on by Indonesia today. PLTH is more reliable and cheaper than the generator with other raw materials and is included in renewable energy [3]. PLTH is divided into several types of generator scale as in Table 1 [4]. At present, there has been a lot of small-scale PLTH development and a spread generator. Small-scale PLTH has been developed a lot lately and has become one of the alternatives for fulfilling electrical energy, especially difficult areas that are affordable and remote [2]. PLTH is built in areas that have river potential throughout the year.

Table 1. PLTH Classification [4]

\begin{tabular}{lc}
\hline PLTH & Power \\
Classification & $>100 \mathrm{MW}$ \\
Large & $15-100 \mathrm{MW}$ \\
Medium & $1-15 \mathrm{MW}$ \\
Small & $100 \mathrm{~kW}-1 \mathrm{MW}$
\end{tabular}


ICOSITER 2018 Proceeding

Journal of Science and Applicative Technology

Micro

$5-100 \mathrm{~kW}$

Pico

$<5 \mathrm{~kW}$

Small-scale PLTH has several advantages including [3]:

a. PLTH can be built, managed independently, and owned by consumers / local communities

b. Operating, maintenance and repair systems by local technicians

c. The generator can use the runoff river system, the weir height is $<2 \mathrm{~m}$, without a dam and the dam is not wide

d. Built with components commonly used in engineering construction and available in the local market; generators, cables, transmission belts, pipes, etc.

e. The type of turbine can be made by a local workshop; cross-flow turbine

f. emission free, low maintenance costs and long life

\section{Results and Discussion}

The study of the potential for PLTH development is carried out with the following methods [5]:

a. Determination of river location

b. Measurement of the height of falling water

c. Measurement of water discharged

d. Calculation of potential generated power and annual energy

Some of the measuring instruments needed for this study are GPS, Current meter-flowatch and meter and other supporting equipment. The rivers that are the target of the survey are large rivers based on local directives. The river measured is 5 large rivers spread in several villages in the North West Coast (Way Laai, Way Lami / Malaya, Way Mlesom, Way Kendaway and Way Lemong). The Way Laai River is a meeting between two rivers and the left. Potential measurements are carried out as a calculation of Hydro potential in general, namely using equations [4]

$$
\mathrm{P}=\mathrm{g} \times \mathrm{h} \times \mathrm{Q} \times \eta
$$

Where :

$$
\begin{aligned}
& P=\text { output power generated }(\mathrm{kW}) \\
& \mathrm{g}=\text { gravity }(9.8 \mathrm{~m} / \mathrm{s} 2) \\
& \mathrm{h}=\text { height of water falling }(\mathrm{m}) \\
& Q=\text { river water discharge }(\mathrm{m} 3 / \mathrm{s}) \\
& \eta=\text { efficiency }
\end{aligned}
$$

From the results of the calculation of the initial study of the rivers surveyed. There are two potential rivers for PLTH development, namely Way Laai River (Left Intersection Way) and Way Lami (Table 2) which have a gross output power that can be generated $\pm 1 \mathrm{MW}$. For design discharge, it is calculated based on the measurement results by designing $85 \%$ of the water discharge.

Table 2. Design Discharge and Effective Head 
ICOSITER 2018 Proceeding

Journal of Science and Applicative Technology

\begin{tabular}{lccc}
\hline & $\begin{array}{c}\text { Way Kanan } \\
\text { (Laai) }\end{array}$ & Way Laai & $\begin{array}{c}\text { Way } \\
\text { lami }\end{array}$ \\
\hline Measured Q $\left(\mathrm{m}^{3} / \mathrm{s}\right)$ & 2.21 & 5.65 & 6.67 \\
$\begin{array}{l}\text { Q design = measurable Q } \\
85 \%\left(\mathrm{~m}^{3} / \mathrm{s}\right)\end{array}$ & 1.77 & 4.52 & 5.336 \\
The measuring Head (m) & & 46 & 30 \\
effective Head (m) & & 44.16 & 28.8 \\
$\begin{array}{l}\text { minimum effective Head } \\
(\mathrm{m})\end{array}$ & & 37.536 & 24.48 \\
\hline
\end{tabular}

The parameters in Table 2 are used as input data in the Annual Energy calculation using the help of CaSiMir software. In calculating Annual energy, intake efficiency, turbines and generators are used with an approximate value of $60 \%$, namely $\pm 80 \%$ generator and $\pm 60 \%$ turbine [6].

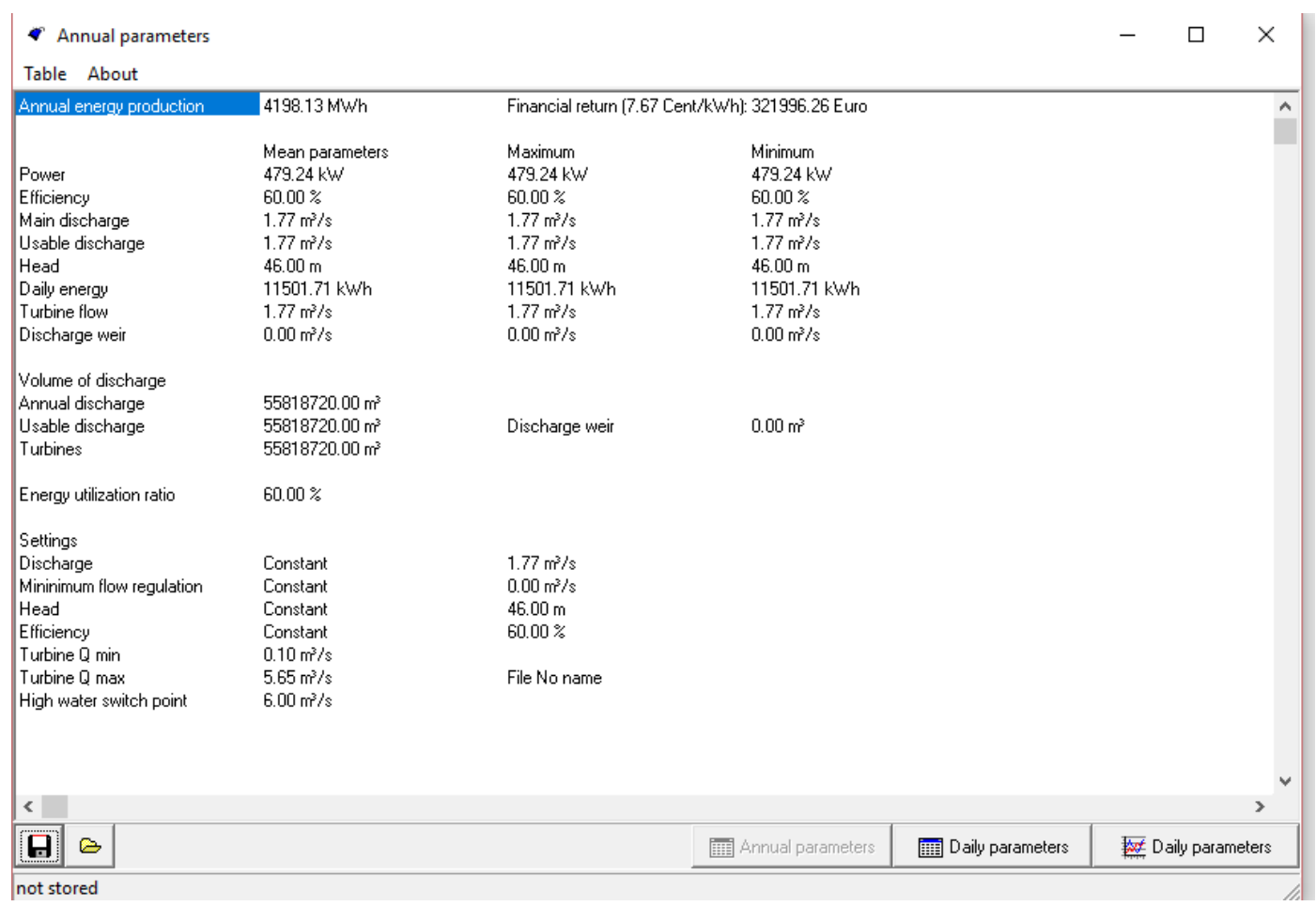

Figure 1. Annual Energy of Way Kanan

The calculation results using Hydropower CaSiMiR show that the way river with minimum discharge conditions ( Way Kanan) can produce turbine mechanical power $479.24 \mathrm{~kW}$ where the daily energy reaches $11501.71 \mathrm{kWh}$, annual energy 4198.13 MWh (Figure 1). While the calculations for Way Laai obtained a mechanical output power of $1223.82 \mathrm{~kW}$ with daily energy reaching $29371.61 \mathrm{kWh}$, annual energy 10720.64 MWh (Figure 2). Mechanical output for the Way Lami river was $942.23 \mathrm{~kW}$ and daily energy $22613.54 \mathrm{kWh}$, annual energy 8253.94 MWh which can be seen in Figure 3. Based on these data, the two rivers have the potential for a Mini Hydro plant. 
ICOSITER 2018 Proceeding Journal of Science and Applicative Technology

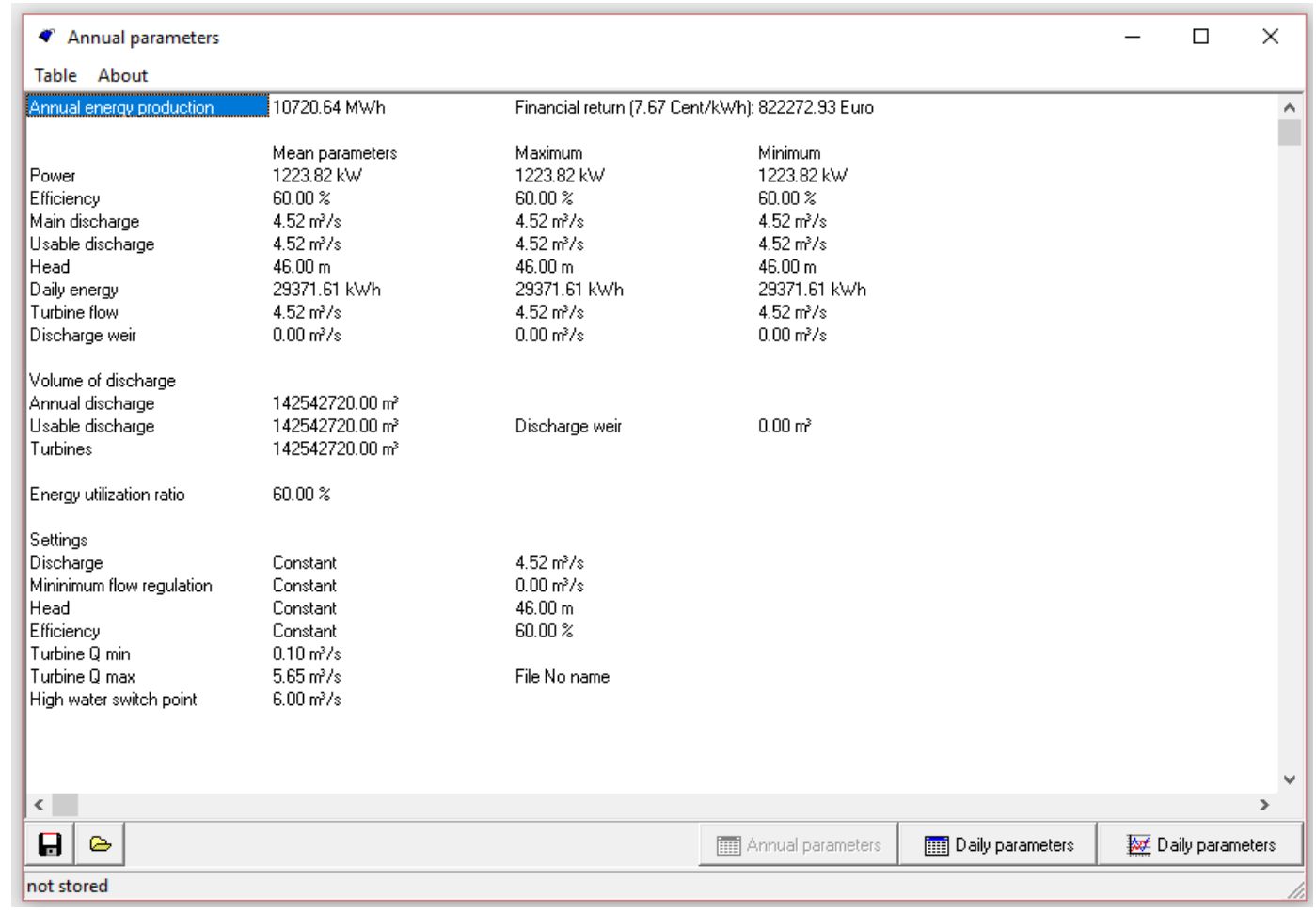

Figure 2. Annual Energy of Way Laai

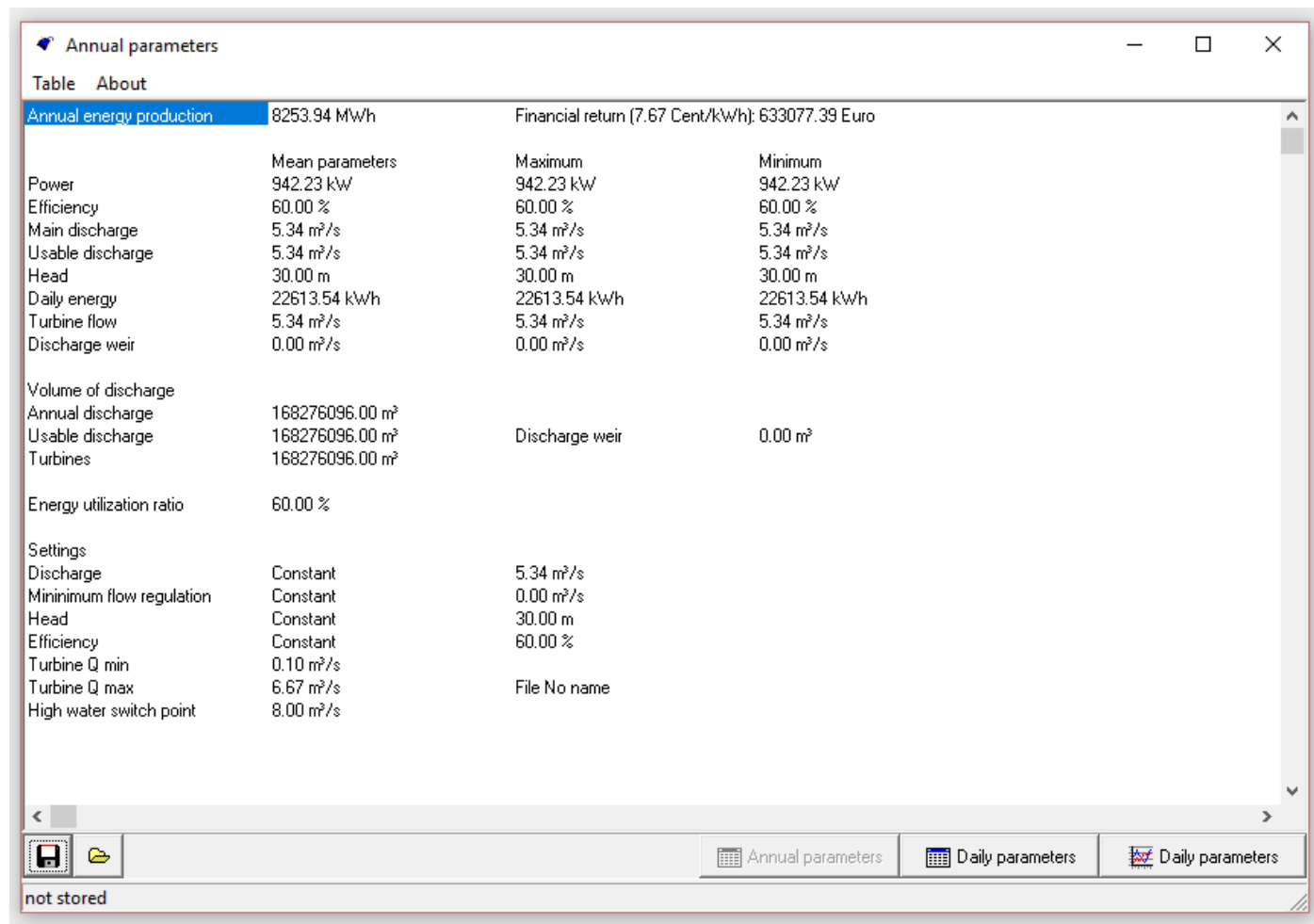


ICOSITER 2018 Proceeding

Journal of Science and Applicative Technology

Figure 3 Annual Energy of Way Lami

Mechanical output power of the Way Laai and Way Lami rivers is estimated to be able to meet the electricity needs of the community with an installed power of 900VA as much as $\pm 530, \pm 1350, \pm 25100$ Houses. This calculation is estimated to operate alone, isolated plants. However, for further studies, feasibility studies and detailed river surveys must be conducted regarding development feasibility and financial feasibility.

For conditions where the plant is connected to the PLN network. In terms of the development of this plant, it is also very supportive in repairing voltage falls at the tip of the feeder distribution network of PLN. The generation of PLTH can be connected to the PLN feeder voltage 220V with the existence of a system of buying and selling energy. Where this activity is based on the Minister of Energy and Mineral

Resources Regulation No. 12 of 2014 and the National Minister of Foreign Affairs Decree No. 0357 of 2014 concerning the provision of connecting water-based renewable energy plants to the PLN network. Another policy in Government Regulation No. 14 of 2012 concerning electricity supply business activities. Energy generated from MHP can be sold to the PLN for the next.

\section{Conclusion}

Based on the analysis of the results of the initial survey, it can be concluded that there are two rivers that have the potential to become a micro or mini hydro generator. Way Laai and Way Lami. The maximum design discharge of Way Laai of $4.52 \mathrm{~m} 3 / \mathrm{s}$ can produce a mechanical output power of $1223.82 \mathrm{~kW}$ with an effective head of $44.16 \mathrm{~m}$. Way Lami with a design discharge of 5,336 m3 / s, an effective head of 28.8 $\mathrm{m}$ has the potential to provide a mechanical power output of $942.23 \mathrm{~kW}$. With the mechanical output power of the sequential Way Laai and Way Lami rivers, it is estimated that it can meet the electricity needs of the community with an installed power of 900VA as much as $\pm 1350, \pm 25100$ Houses.

\section{Acknowledgements}

The authors would like thank to Institut Teknologi Sumatera for the financial support by BOPTN funding through institute competitive research in 2018 (No. 134an/IT9.C1/PP/2018)

\section{REFERENCES}

[1] Kananda, Kiki. 2017. Preliminary Study of Solar Energy Potential in Lampung Region: Case Study The Campus of the Institut Teknologi Sumatera (ITERA) Towards Smart Campus. Journal of Science and Applicative Technology Vol. I No.2

[2] Sukmawidjaja, Maula and Akbar, Ilham. 2013. Simulation of PLTH System Optimization Using Homer Software to Save Fuel Usage on Penyengat Island Tanjung Pinang, Riau Islands. JETri Volume 11 number 1 August 2013 Page 17-42 ISSN 1412-0372

[3] Doda, Nurhayati and Mohammad, Herdi. 2018. Analysis of the Potential Development of Microhydro Power Plants in Bone Bolango District. Gorontalo Journal of Infrastructure \& Science Engineering Volume 1 No. 1 April 2018 
ICOSITER 2018 Proceeding

Journal of Science and Applicative Technology

[4] Jamali, Firman. _. Planning Study of Minihodro Power Projects Supported by Turbinpro Program in Sinar Pekayau Village, Sepauk District, Sintang District. Electrical Engineering Study Program, Faculty of Engineering, University of Tanjungpura

[5] Subekti, Ridwan Arief.2010. The survey of the potential of micro hydropower plants in Kuta Malaka, Aceh Regency, is a large province of Aceh Darussalam. Journal of mechatronics, electrical power and ventricular technology Vol 01 No. 1 ISSN 2087-3379

[6] Shaufi, Faqri. _. Study of the Potential of Micro Hydro Power Plants (PLTMH) Assisted by the Casimir Program in the Pagung Riam of Sanatab Village, Sajingan Besar District, Sambas Regency. Electrical Engineering Study Program, Faculty of Engineering, University of Tanjungpura 